\title{
Хірургічне лікування гігантської первинної ліпосаркоми великого сальника з розповсюдженим перитонеальним обсіменінням
}

Представлено клінічний випадок хірургічного лікування гігантської первинної ліпосаркоми великого сальника з розповсюдже-
ним перитонеальним саркоматозним обсіменінням (PCI = 22). Після обстеження та вирішення питання про можливість вида-
лення пухлини або циторедукції, а також, враховуючи прогестеруючу кишкову непрохідність, прийнято рішення про виконан-
ня операційного втручання: виконано видалення первинної пухлини, тотальну колектомію та перитонектомію в межах повної
оптимальної циторедукції (СС-0), тобто з відсутністю видимих перитонеальних вогнищ, згідно з Completeness of суtoreduction
Score (СС). Операція завершена формуванням апаратного ілео-ректального латеро-термінального анастомозу з протективною
ілеостомою за Торнболлом. Остання закрита через 6 місяців після первинної операції. Медіана спостереження склала 21 місяць.

Ключові слова: ліпосаркома; циторедукція; індекс перитонеального обсіменіння.

Пухлини жирової тканини є найчастішими доброякісними або злоякісними новоутвореннями м'яких тканин, можуть мати різну локалізацію [1]. Саркоми частіше діагностують у пацієнтів у $40-60$ років із співвідношенням чоловіків та жінок 2:1 [2]. Серед всіх злоякісних пухлин ліпосаркоми трапляються $<1 \%$ випадків, $є$ новоутвореннями мезодермального походження з жирової тканини, складають 10-14 \% від всіх сарком, посідаючи друге місце серед найбільш поширених сарком м'яких тканин у дорослих.

Локалізація ліпосарком варіабельна, вони можуть виникати в будь-якій частині тіла: нижні кінцівки $є$ найбільш поширеним місцем локалізації пухлин [3], що становить 46 \% від всіх діагностованих випадків, верхні кінцівки уражаються значно рідше - $13 \%$. Заочеревинний простір $€$ наступною найбільш частою локалізацією і становить від 12 до 20 \% від усіх ліпосарком, в 19 \% діагностуються ураження тулуба і в 9 \% ураження голови та шиї [2, 3]. Дуже рідко трапляється первинна інтраабдомінальна локалізація ліпосарком [4], близько 5 \% випадків [5]. Саркоми становлять групу гетерогенних пухлин із різною генетичною основою. Ліпосаркома має декілька ліпогенних типів пухлини, які відрізняються клінічно і гістогенетично [1]. Виділяють три основні підтипи ліпосаркоми: високодиференційовану, низькодиференційовану, міксоїдну і плеоморфну [6].

П'ятирічна виживаність може варіювати від 41,9 \% при високодиференційованних саркомах до 7,8 \% при низькодиференційованих [5]. Особливість ліпосарком інтраабдомінальної локалізації полягає не тільки в низькій частоті, а й у відсутності специфічної клінічної симптоматики, ці пухлини можуть прогресувати протягом тривалого часу, не спричиняючи виражених симптомів і на момент встановлення діагнозу пухлина часто досягає значних розмірів. Можуть виникнути питання на етапі проведення диференціального діагнозу між інтраабдомінальною ліпосаркомою і більш розповсюдженими новоутвореннями черевної порожнини [2]. Клінічно ці пухлини мають тенденцію проявлятися дифузним болем у животі, супроводжуватися анорексією і втратою ваги, збільшенням живота в об'ємі. Симптоматика неспецифічна i, в основному, зумовлена компресією органів черевної порожнини, що спостерігається у 80 \% випадків [7]. Мезенхімальні структури мають хороше кровопостачання, але обмежену лімфатичну дренажну систему, що, ймовірно, зумовлює характер метастазування злоякісних мезенхімальних пухлин. Тенденція до дисемінації саркоми в лімфатичні вузли помітно відрізняється від епітеліальних злоякісних новоутворень, які метастазують як лімфогенним, так і гематогенним шляхом.

На противагу цьому мезенхімальні злоякісні пухлини частіше метастазують гематогенно, в результаті чого метастази виявляють у легенях або печінці, але рідко в лімфатичних вузлах. У цілому, частота метастазування низька і становить 7 \% (метастатичне ураження регіональних лімфатичних вузлів спостерігається лише у 13 \% пацієнтів з метастатичною саркомою м'яких тканин), порівняно з іншими гістологічними підтипами саркоми, показники метастазування яких варіюють від 15 до 34 \% [7, 2]. 3 огляду на низький показник частоти метастазування, експансивний ріст пухлини, досягнення великих розмірів, хірургічне лі- 
кування $є$ золотим стандартом для лікування ліпосарком черевної порожнини [7]. Радикальна резекція навіть великої пухлини пов'язана 3 довгостроковим виживанням пацієнтів $[7,8]$.

Радикальний принцип лікування полягає в блочному висіканні первинної пухлини і залучених у процес прилеглих структур і органів якомога далі від псевдокапсули саркоми. Основним фактором, що визначає резектабельність пухлини, є ступінь її інвазії в магістральні судини, паренхіму органів, а не розмір пухлини. Хоча передопераційна радіологічна оцінка має важливе значення, резектабельність може бути оцінена остаточно тільки при лапаротомії. Навіть при інвазії пухлини в життєво важливі структури більшість сарком є резектабельною. Більшість випадків рецидиву інтраабдомінальних сарком локалізується на парієтальній очеревині, частота саркоматозного обсіменіння очеревини при абдомінальній саркомі коливається від 35 до 82 \% [5]. Наявність саркоматозного обсіменіння парієтальної очеревини пов'язана з високим ризиком рецидиву i, відповідно, низькою медіаною виживання. Існують уніфіковані протоколи циторедуктивної хірургії і внутрішньочеревної хіміотерапії, основаної на гістологічному типі пухлини та їі чутливості до хіміопрепаратів [2, 8]. Ефективність циторедукції корелює з показниками її обсягу, повноти оптимальної циторедукції - CС-0, тобто відсутності видимих перитонеальних вогнищ, згідно з Completeness of cytoreduction Score (CC) - незалежно від кількості множинних рецидивів - $є$ стандартом циторедуктивної хірургії при перитонеальному канцероматозі i, як було показано, технічно здійсненна і значно впливає на швидкість OS i DFS. Salti et al. повідомили про більш високу статистично значущу середню DFS i OC у пацієнтів з оптимальною (CC-0) і субоптимальною ( $\geq \mathrm{CC}-1)$ циторедукцією (DFS: 27,3 проти 4,3 місяці, відповідно, OS: 35,3 проти 5,3 місяці, відповідно) [9, 10]. Вплив РСІ- індексу перитонеального канцероматозу або індексу Sugarbaker [12] було вивчено раніше, так Berthet et al. повідомили про більш високу 5-річну OS у пацієнтів з PCI <13, ніж у пацієнтів з РCI> 13 (75 \% проти 12,8 \%, відповідно) [12, 13].

Представляємо власне клінічне спостереження хірургічного лікування первинної ліпосаркоми великого сальника з саркоматозним обсіменінням парієтальної очеревини, всього очеревинного покриву товстої кишки та її брижі.

Клінічний випадок. Пацієнт К., 50 років, 11.01.16. р. госпіталізований в хірургічне відділення Київської міської клінічної лікарні № 18 зі скаргами на збільшення живота в розмірах, біль у животі, загальну слабість, явища прогресуючої кишкової непрохідності протягом останніх 6 місяців. На момент звернення обстежений в обласній лікарні за місцем проживання, спеціалізованих онкологічних центрах. Хворому виконано колоноскопію, за результатом якої виявлено гіперемію слизової оболонки, без наявності органічної патології і деформація сигмоподібної кишки за рахунок стиснення ззовні; ЕФГДС - хронічний гастродуоденіт, деформація тіла шлунка за рахунок стиснення ззовні; урографія з внутрішньовенним контрастуванням - функція обох нирок в нормі. Зліва ЧЛС погано візуалізується, ймовірно, за рахунок нашарування стінки новоутворення черевної порожнини, структура не змінена. Сечовід і сечовий міхур у нормі. На СКТ органів черевної та грудної порожнини виявлено позаорганне новоутворення, без інвазії великих судин. Печінка без вогнищевих уражень, патології в легенях не виявлено, іншої інформації не надано. Результати визначення рівнів онкомаркерів: ПСА - 0,803 нг / мл, АПФ - 3,44 нг / мл, РЕА - 1,83 нг / мл, СА 19-9: 3,94 ОД / мл, СА 72-4: 0,99 ОД / мл. Також у показниках загального аналізу крові, сечі, біохімічного аналізу крові, коагулограми не виявлено відхилень від референтних значень. Результати біопсії пункції новоутворення черевної порожнини - елементи ліпосаркоми. Висновок хіміотерапевта - враховуючи розмір пухлини, гістологічний варіант - ліпосаркома, пухлина хіміорезистентна, хіміотерапія не показана. Хворому встановлено діагноз: заочеревинна ліпосаркома. В операційному лікуванні за місцем проживання пацієнту було відмовлено.

У клініці пацієнта дообстежено. На підставі отриманих КТ-зображень виявлено новоутворення черевної порожнини з поширенням у малу миску, що не має чіткої органної належності, новоутворення кровопостається за рахунок гілок черевного стовбура, інвазії в великі судини не виявлено, печінка та легені без вогнищевих уражень.

Показники внутрішньочеревного тиску, отримані шляхом вимірювання трансвезикальним методом 3 використанням катетера Фолея, склали 13 мм рт. ст., що відповідає першому степеню внутрішньочеревної гіпертензії [14].

3 огляду на недоцільність консервативних методів лікування, потенційну резектабельність новоутворення прийнято рішення про проведення операційного втручання. 25.01.16 р. виконано лапаротомію: черевну порожнину виповнює пухлина від входу в малу миску до діафрагми, з основним джерелом кровопостачання з гілок правих шлунковосальникових судин і найбільш імовірним джерелом росту з великого сальника. Визначено множинне саркоматозне обсіменіння парієтальної очереви- 


\section{ПОВІДОМЛЕННЯ}

ни малого таза, в правій і лівій здухвинних ділянках правого купола діафрагми, обох фланків живота, очеревинного покриву всієї ободової кишки, очеревини ії брижі. Вісцеральна очеревина тонкої кишки втягнена в патологічний процес тільки на відстані 30 см від ілеоцекального кута.

Розповсюдження саркоматозного обсіменіння оцінено за допомогою РСI, який склав 22 [11].

Видалено основний масив пухлини, після чого виконано тотальну колектомію, розширену до низької передньої резекції прямої кишки в єдиному блоці з парієтальної очеревиною, від діафрагмальних листків, бічних стінок живота до кореня брижі і повним видаленням очеревини прямокишково-міхурового поглиблення. Циторедукція виконана в повному обсязі, без резидуальних вогнищ саркоматозного обсіменіння (СС-0) [11]. Сформоровано апаратний ілео-ректальний латеро-термінальний анастомоз із проективною ілеостомою за Торнболлом у лівій клубовій ділянці живота. Черевна порожнина дренована ПХВ дренажами: по лівому і правому фланках, піддіафрагмальному просторі.

Результати інтраопераційного ПГЗ - міксоїдний варіант ліпосаркоми. Враховуючи попередній висновок хіміотерапевта, внутрішньоочеревинну ПХТ не проводили. ПГЗ № 44-45; 46-47 від 26.01.2016 р. : малоклітинна міксоїдна ліпосаркома. Імуногістохімічне дослідження № 050-053/II від 28.01.2016 р. : імуногістохімічне дослідження свідчить на користь малоклітинної міксоїдної лі-

\section{СПИСОК ЛІТЕРАТУРИ}

1. Fisher C. Atlas of soft tissue tumor pathology / C. Fisher. Atlas of Anatomic Pathology Springer Science+Business Media, LLC 2013

2. Paul Sugarbaker H. Management of abdominopelvic sarcoma / Paul H. Sugarbaker. - Malawer Chapter, 2001.

3. Primary mesenteric liposarcoma: An unusual presentation of a rare condition / Sudhir Kumar Jain, AparajitaMitra, Ram Chandra Murthy Kaza, Sunil Malag // J. Gastrointest. Oncol. 2012. - Vol. 3 (2)

4. Rajshekhar Patil. Liposarcoma of greater omentum: a case report on rarity of tumor localization / Rajshekhar Patil, Happykumar Kagathara // Journal of Case Reports. - 2014. - Vol. 4, No. 2.

5. Kazim Duman. A case report: Giant intra-abdominal liposarcoma presenting acute renal failure / KazimDuman, Mustafa Girgin, Gokhan Artas // Ann. Med. Surg. (Lond). - 2016. Vol. 12. - P. 90-93.

6. Rachel Conyers. Liposarcoma: molecular genetics and therapeutics / Rachel Conyers, Sophie Young, David M. Thomas // Sarcoma. - 2011;

7. Giant retroperitoneal liposarcoma / Ángel Herrera-Gómez, César Ortega-Gutiérrez, Alejandro Mohar [et al.] // World J. Surg. Oncol. - 2008. - Vol. 6. - P. 115.

8. National Comprehensive Cancer Network/ NCCN Clinical посаркоми (Ki-67 - 10 \%) з вираженим ангіоматозом.

На 16 добу пацієнт без ускладнень виписаний зі стаціонару і направлений на повторну консультацію хіміотерапевта. Після проходження хіміотерапії, через 6 місяців виконана СКТ ОЧП. Ознак prolongatiomorbi не виявлено, в зв'язку з чим виконана реконструктивно-відновлювальна операція - закриття ілеостоми. У задовільному стані виписаний зі стаціонару. За період спостереження 21 місяць - даних за prolongatiomorbi не виявлено.

Висновки. 1. Первинні ліпосаркоми великого сальника трапляються вкрай рідко. Особливістю інтраабдомінальної локалізації пухлини є її тривале прогресування і пізній прояв клінічних симптомів, специфіка яких залежить від ступеня компресії або інвазії сусідніх структур, що призводить до пізньої діагностики, на етапах, коли пухлина досягає великих розмірів. Враховуючи рідкість інтраабдомінальної локалізації ліпосарком, диференціальна діагностика з іншими пухлинними утвореннями черевної порожнини може бути досить складною.

2. Єдиним параметром резектабельності ліпосаркоми є ступінь її інвазії в сусідні структури.

3. Радикальне видалення пухлини і уражених сусідніх структур рекомендоване при лікуванні первинної ліпосаркоми великого сальника.

4. Високий PCI не є протипоказанням до проведення перитонектомії і може продовжити виживаність у хворих із саркоматозом черевної порожнини.

Practice Guidelines in Oncology (NCCN Guidelines 2017

9. Liposarcomas: treatment and outcome, a retrospective singlecenter study / M. Glehr, A. Leithner, S. Scheipl [et al.] // Eur. Surg. - 2009. - Vol. 41. - P. 163-169.

10. Multiple liposarcoma of mesentery and mesocolon / M. Soufi, M. K. Lahlou, O. Benzekri [et al.] // J. Afr. Cancer. - 2009. Vol. 1. - P. 1-5.

11. Peritoneal carcinomatosis: Limits of diagnosis and the case for liquid biopsy / R. W. James McMullen, Matthew Selleck, Nathan R. Wall, Maheswari Senthil // Onkotargent. - 2017.

12. Peritoneal sarcomatosis: is there a subset of patients who may benefitfrom cytoreductivesurgery andhyperthermicintraperitoneal chemotherapy? / D. Baratti, E. Pennacchioli, S. Kusamura [et al.] // Ann. Surg. Oncol. - 2010. - Vol. 17 (12). - P. 32203228.

13. Cytoreductive surgery plus hyperthermic intraperitoneal chemotherapy for management of peritoneal sarcomatosis: a preliminary single-center experience from Saudi Arabia / Ahmed Abu-Zaid, Ayman Azzam, Mohammed Abuzaid [et al.] // Gastroenterol. Res. Pract. - 2016. - P. 6567473.

14. Patrick Maluso. Abdominal compartment hypertension and abdominal compartment syndrome / Patrick Maluso, Jody Olson, Babak Sarani // Crit. Care Clin. - 2015. 


\section{REFERENCES}

1. Fisher, C. (2013). Atlas of soft tissue tumor pathology. Atlas of Anatomic Pathology Springer Science+Business Media, LLC. 2. Paul Sugarbaker, H. (2001). Management of abdominopelvic sarcoma. Sugarbaker: Malawer Chapter.

3. Sudhir Kumar Jain, Aparajita Mitra, Ram Chandra Murthy Kaza, \& Sunil Malag (2012). Primary mesenteric liposarcoma: An unusual presentation of a rare condition, J. Gastrointest. Oncol., 3 (2)

4. Rajshekhar Patil \& Happykumar Kagathara (2014). Liposarcoma of greater omentum: a case report on rarity of tumor localization. Journal of Case Reports, 4 (2).

5. Kazim Duman, Mustafa Girgin, \& Gokhan Artas (2016). A case report: Giant intra-abdominal liposarcoma presenting acute renal failure. Ann. Med. Surg. (Lond), 12, 90-93.

6. Rachel Conyers, Sophie Young, \& David M. Thomas (2011). Liposarcoma: molecular genetics and therapeutics. Sarcoma.

7. Ángel Herrera-Gómez, César Ortega-Gutiérrez, \& Alejandro Mohar (2008). Giant retroperitoneal liposarcoma. World J. Surg. Oncol., 6, 115.

8. (2017). National Comprehensive Cancer Network. NCCN Clinical Practice Guidelines in Oncology (NCCN Guidelines).
9. Glehr, M., Leithner, A., \& Scheipl, S. (2009). Liposarcomas: treatment and outcome, a retrospective single-center study. Eur. Surg., 41, 163-169.

10. Soufi, M., Lahlou, M.K., \& Benzekri, O. (2009). Multiple liposarcoma of mesentery and mesocolon. J. Afr. Cancer, 1, 1-5. 11. James McMullen, R.W., Matthew Selleck, Nathan R. Wall, \& Maheswari Senthil (2017). Peritoneal carcinomatosis: Limits of diagnosis and the case for liquid biopsy. Onkotargent.

12. Baratti, D., Pennacchioli, E., \& Kusamura, S.(2010). Peritoneal sarcomatosis: is there a subset of patients who may benefit from cytoreductive surgery and hyperthermic intraperitoneal chemotherapy? Ann. Surg. Oncol., 17 (12), 32203228.

13. Ahmed Abu-Zaid, Ayman Azzam, \& Mohammed Abuzaid (2016). Cytoreductive surgery plus hyperthermic intraperitoneal chemotherapy for management of peritoneal sarcomatosis: a preliminary single-center experience from Saudi Arabia. Gastroenterol. Res. Pract., 6567473.

14. Patrick Maluso, Jody Olson, Babak Sarani (2015). Abdominal compartment hypertension and abdominal compartment syndrome. Crit. Care Clin.

\title{
L. S. BILYANSKYI, E. Y. MIROSHNICHENKO, A. D. KALCHENKO, D. I. BYTENKO
}

O. Bohomolets National Medical University

Kiyv City Hospital No. 18

\section{SURGICAL TREATMENT OF GIANT PRIMARY LIPOSARCOMA OF OMENTUM WITH ADVANCED PERITONEAL SARCOMATOSIS DISSEMINATION}

\begin{abstract}
We present clinical case of a primary liposarcoma of the giant omentum with progressive peritoneal sarcomatosis PCI $=22$ ) which we treated surgically. After the examination and the decision on the possibility of removing the tumor, or cytoreduction, as well as the problems of the progressive intestinal obstruction, surgical intervention was carried out in the volume: removal of the primary tumor, total colectomy and peritonectomy in the volume of complete optimal cytoreduction (CC-0), with absence of visible peritoneal focuses, according to Completeness of cytoreduction Score (CC). The operation was completed by the formation of a illeorectal-rectal lateroterminal anastomosis with protective ileostomy by Thornboll, which was closed after 6 months. Median follow-up was 21 months.
\end{abstract}

Key words: liposarcoma; citoreduction; peritonealcancerindex.

Л. С. БЕЛЯНСКИЙ, Е. Ю. МИРОШНИЧЕНКО, А. Д. КАЛЬЧЕНКО, Д. И. БУТЕНКО

Национальный медицинский университет имени А. А. Богомольца, Киев

Киевская городская клиническая больница № 18

\section{ХИРУРГИЧЕСКОЕ .ЛЕЧЕНИЕ ГИГАНТСКОЙ ПЕРВИЧНОЙ ЛИПОСАРКОМЫ БОЛЫШОГО САЛЬНИКА С РАСПРОСТРАНЕННЫМ ПЕРИТОНЕАЛЬНЫМ ОБСЕМЕНЕНИЕМ}

\footnotetext{
Представлен клинический случай хирургического лечения гигантской первичной липосаркомы большого сальника с распространенным перитонеальным саркоматозным обсеменением (PCI = 22). После обследования и решения вопроса о возможности удаления опухоли или циторедукции, а также, учитывая проблемы с прогрессирующей кишечной непроходимостью, выполнено оперативное вмешательство в объеме: удаления первичной опухоли, тотальной колэктомии и перитонэктомии в объеме полной оптимальной циторедукции (CC-0), то есть отсутствием видимых перитонеальных очагов, согласно Completeness of cytoreduction Score (CC). Операция закончена формированием аппаратного илео-ректального латеро-терминального анастомоза с протективной илеостомой по Торнболлу, закрытой через 6 месяцев.

Медиана послеоперационного наблюдения составила 21 месяц.
}

Ключевые слова: липосаркома; циторедукция; индекс перитонеального обсеменения. 